DANIEL J. B. MITCHELL

University of California, Los Angeles

\title{
Shifting Norms in Wage Determination
}

IN 1980, I noted three characteristics of the U.S. union labor market: a tendency for union wage increases to outpace nonunion, an insensitivity of wage decisions to real demand conditions, and a gradual erosion of the membership base. ${ }^{1}$ In 1982, as dramatic developments in the determination of union wages began to unfold, I reported on a series of wage concessions that had been negotiated in industries as diverse as automobile manufacturing, intercity trucking, and meatpacking. ${ }^{2}$ Despite the widespread concessions, however, it was impossible at that time to detect any substantial change in the union labor market as described above.

With an additional three years of observation permitting firmer conclusions, I explore here an apparent union wage norm shift and its implications for wage determination generally over the next few years. Four basic points are made. First, union wage indexes have recently been rising at surprisingly slow rates, given economic circumstances. Second, various institutional developments in the union sector reinforce the evidence of a wage norm shift. Third, the form of union wage concessions made in the past few years suggests that future union wage growth will be moderate and somewhat less responsive to price inflation than it was in the past. Fourth, the union sector is large enough to affect aggregate wage indexes, even if no norm shift has occurred in the nonunion sector.

\section{Union Wage Concessions}

The phenomenon of union wage concessions is not new. What is new in the 1980 s is their volume. As table 1 indicates, since 1982 substantial

1. Daniel J. B. Mitchell, Unions, Wages, and Inflation (Brookings, 1980).

2. Daniel J. B. Mitchell, "Recent Union Contract Concessions," BPEA, 1:1982, pp. 165-201. 
Table 1. Proportion of Workers under Major Private Union Settlements with Concessions and with Substantial Real Wage Declines, 1959-85

Percent

\begin{tabular}{|c|c|c|c|c|}
\hline \multirow[b]{2}{*}{ Year } & \multirow{2}{*}{$\begin{array}{l}C P I-W \\
\text { inflation } \\
\text { rate } \\
(1)\end{array}$} & \multicolumn{2}{|c|}{$\begin{array}{l}\text { Proportion of workers } \\
\text { with freezes and cuts }\end{array}$} & \multirow{2}{*}{$\begin{array}{c}\text { Proportion of workers } \\
\text { with settlements } 3.3 \\
\text { percentage points } \\
\text { below CPI-W inflation } \\
\text { (4) }\end{array}$} \\
\hline & & $\begin{array}{l}\text { Freezes } \\
\text { and cuts } \\
\text { (2) }\end{array}$ & $\begin{array}{l}\text { Cuts } \\
\text { (3) }\end{array}$ & \\
\hline 1959 & 1.5 & 3 & 0 & 0 \\
\hline 1960 & 1.5 & 4 & 0 & 0 \\
\hline 1961 & 0.7 & 7 & 0 & 0 \\
\hline 1962 & 1.2 & 22 & 0 & 0 \\
\hline 1963 & 1.6 & 25 & 0 & 0 \\
\hline 1964 & 1.2 & 5 & 0 & 0 \\
\hline 1965 & 1.9 & 4 & 0 & 0 \\
\hline 1966 & 3.4 & 1 & 0 & 1 \\
\hline 1967 & 3.0 & 1 & 0 & 0 \\
\hline 1968 & 4.7 & 0 & 0 & 0 \\
\hline 1969 & 6.1 & 1 & 0 & 1 \\
\hline 1970 & 5.5 & 0 & 0 & 0 \\
\hline 1971 & 3.4 & 1 & 0 & 1 \\
\hline 1972 & 3.4 & 3 & 0 & 3 \\
\hline 1973 & 8.8 & 1 & 0 & 41 \\
\hline 1974 & 12.2 & 1 & 0 & 39 \\
\hline 1975 & 7.0 & 4 & 0 & 9 \\
\hline 1976 & 4.8 & 4 & 0 & 6 \\
\hline 1977 & 6.8 & 2 & 0 & 9 \\
\hline 1978 & 9.0 & 2 & 0 & 31 \\
\hline 1979 & 13.4 & 4 & 0 & 52 \\
\hline 1980 & 12.5 & 0 & 0 & 50 \\
\hline 1981 & 8.7 & 8 & 5 & 13 \\
\hline 1982 & 3.9 & 44 & 2 & 45 \\
\hline 1983 & 3.3 & 37 & 13 & 37 \\
\hline 1984 & 3.5 & 23 & 5 & 25 \\
\hline $1985^{\mathrm{b}}$ & 4.2 & 26 & 4 & $28^{\mathrm{c}}$ \\
\hline
\end{tabular}

Source: Current Wage Developments, various issues.

a. Concessions are first-year wage freezes or cuts. Estimates in column 4 are based on interpolation. Figures are rounded to the nearest whole number. CPI-W inflation is on a December-to-December basis, except 1985, which is on a December-to-June basis.

b. First six months.

c. Preliminary.

fractions of workers under newly negotiated "major" private union contracts have had their first-year wages frozen or cut. Because some workers may have received more than one wage freeze or cut, it is not possible to estimate precisely the proportion of such workers experienc- 
ing at least one concession. However, the fraction can be estimated at between one-third and one-half under alternative assumptions. ${ }^{3}$

Could table 1 simply reflect the recent disinflation? Since price inflation variables inevitably show strong explanatory power in wage-change studies, perhaps real wage freezes and cuts are to be expected in periods of low inflation, as the mean of the wage-change distribution drifts downward. In fact, the available evidence does not bear out such an interpretation.

The year of lowest inflation in the early 1980 s as measured by the CPI$\mathrm{W}$, the consumer price index for urban wage earners and clerical workers, was 1983. A worker experiencing a wage freeze in that year would have suffered a real wage loss of 3.3 percent as measured by CPI-W. Column 4 of table 1 shows, for each year from 1959 to 1985, the proportion of workers with contracts providing first-year basic wage adjustments of 3.3 percentage points below CPI-W inflation.

In the early 1960s, when measured inflation was less than 2 percent, virtually no workers received wage settlements 3.3 percentage points below CPI-W. In two years, 1962 and 1963, significant proportions of workers under newly negotiated contracts received wage freezes, but the low inflation rate ensured that their real wage loss was well under 3.3 percent. Nor do productivity growth differences appear to be explanations for the differential wage performance in the two periods; the growth rate of nonfarm productivity in 1962-63 was about the same as in 198384.

The only periods before the 1980s in which substantial proportions of workers suffered such real wage losses were those of accelerating

3. An upper-limit estimate of the proportion of workers in the major union sector who experienced a wage freeze or cut since 1979 can be made by assuming (incorrectly), first, that no worker experienced more than one concession and, second, that the number of workers experiencing concessions in each year reflected the number of workers in that unit as of 1984 as reported in Current Wage Developments. The first assumption leads to an overstatement of the number of workers involved, because some workers did experience more than one concession. The second assumption tends to overstate the number of union workers experiencing concessions, since union membership generally fell in the private sector during the period of concession-making. (Note that the word "concession" is used interchangeably with "first-year wage freeze or cut" throughout this paper.) A lower-limit estimate can be made by taking only the two highest consecutive years of concessionmaking since 1979 , since a worker was unlikely to be covered by two concessions in a twoyear period, and by using the larger 1983 base to compute the fraction. The upper-limit estimate using the methodology described above is 49 percent, and the lower limit is 33 percent. 
inflation, such as 1973-74 and 1978-80. Thus, it appears that until the early 1980s, wage slippage could largely be attributed to unanticipated inflation and a lag in wage responsiveness to price developments. But after 1980, that type of lag should have produced unanticipated real wage gains, not the erosion that actually occurred.

The early 1980 s were characterized not only by disinflation but by high unemployment as well. Perhaps unemployment, a measure of labor demand conditions, accounts for the wage losses of the 1980s. But, again, the evidence does not suggest that the early 1980s was a period of "normal" wage determination. Table 2 shows the actual and predicted performance of six wage indexes (three union-oriented, two aggregate, one nonunion-oriented) during $1980-84$, with predictions based on wage equations estimated over 1959-79. The equations contain a term for current unemployment and lagged price inflation; equations applying to the union sector use a union-oriented measure of unemployment rather than the official rate. Thus differences in economic conditions in union industries as compared with others are reflected in the union-oriented unemployment rate. Also, since the CPI suffered from a methodological problem involving mortgage interest rates (which boosted the index artificially in the late 1970 s and early 1980 s and tended to produce large residuals), an alternative price index has been used in the equations. ${ }^{4}$

4. The regressions run to obtain predicted data for table 2 were of the form of equation 1 in the text, where $p$ is the annual percentage change in the deflator for personal consumption expenditures from the national income accounts lagged one year, and $U^{-1}$ is the current year inverse of an unemployment rate. For the union sector, a union-oriented unemployment rate was estimated by taking sectoral unemployment rates and weighting them by the proportion of union-represented workers in those sectors in 1984. Sectors used were agriculture, mining, durables, nondurables, transportation and public utilities, wholesale and retail trade, finance, insurance and real estate, and services. (Since the data in table 2 refer to the private sector, the government sector was not included in the unionoriented index.) Data on union representation in these sectors appear in Paul O. Flaim, "New Data on Union Members and Their Earnings," Employment and Earnings, vol. 32 (January 1985), pp. 13-14, 208-11. Unemployment rates by sector appear in U.S. Bureau of Labor Statistics, Handbook of Labor Statistics, bulletin 2175 (Washington, D.C.: GPO, 1983), p. 75, and in Employment and Earnings, various issues. The regressions were run on an annual basis over the period 1959-79. The earnings and compensation indexes refer to year-over-year changes; the union wage variables refer to changes within years. Regression results are available from the author. Similar results through mid-1983 are reported in George L. Perry, "What Have We Learned about Disinflation?" BPEA, $2: 1983$, pp. 592-94. It might be noted that if the regressions in table 2 are estimated using CPI-W for all equations and the official unemployment rate for the union wage indexes, similar results are obtained. 
Table 2. Actual and Predicted Wage Changes, 1980-84

Percent

\begin{tabular}{|c|c|c|c|c|c|}
\hline Wage measure & 1980 & 1981 & 1982 & 1983 & 1984 \\
\hline \multicolumn{6}{|c|}{$\begin{array}{l}\text { Median first-year union } \\
\text { wage adjustments }\end{array}$} \\
\hline Actual & 9.4 & 11.0 & 3.7 & 3.7 & 2.2 \\
\hline Predicted & 10.7 & 11.8 & 9.8 & 7.1 & 5.4 \\
\hline \multicolumn{6}{|c|}{$\begin{array}{l}\text { Median first-year union } \\
\text { wage increases }\end{array}$} \\
\hline Actual & 9.4 & 11.0 & 7.1 & 5.8 & 2.9 \\
\hline Predicted & 10.8 & 11.9 & 10.0 & 7.3 & 5.6 \\
\hline \multicolumn{6}{|c|}{$\begin{array}{l}\text { Median effective union } \\
\text { wage adjustments }\end{array}$} \\
\hline Actual & 10.7 & 10.5 & 6.7 & 4.7 & 3.7 \\
\hline Predicted & 10.2 & 11.3 & 9.7 & 7.1 & 5.2 \\
\hline \multicolumn{6}{|l|}{$\begin{array}{l}\text { Change in hourly } \\
\text { earnings index }\end{array}$} \\
\hline Actual & 9.0 & 9.1 & 6.8 & 4.6 & 3.3 \\
\hline Predicted & 9.4 & 10.3 & 8.6 & 6.3 & 4.7 \\
\hline \multicolumn{6}{|c|}{$\begin{array}{l}\text { Change in compensation } \\
\text { per hour }\end{array}$} \\
\hline Actual & 10.3 & 9.6 & 8.0 & 4.9 & 4.1 \\
\hline Predicted & 10.1 & 11.1 & 9.3 & 6.8 & 5.3 \\
\hline \multicolumn{6}{|c|}{$\begin{array}{l}\text { Change in selected } \\
\text { nonunion hourly earnings }\end{array}$} \\
\hline Actual & 7.9 & 8.4 & 5.7 & 5.2 & 4.3 \\
\hline Predicted & 7.6 & 8.3 & 6.8 & 5.0 & 4.1 \\
\hline
\end{tabular}

Sources: Current Wage Developments and author's regression as specified in equation 1. See footnote 4.

a. Union wage indexes refer to major private settlements involving 1,000 or more workers. The hourly earnings index applies to production and nonsupervisory workers in the private, nonfarm sector and is adjusted to exclude the effects of overtime in manufacturing and interindustry employment shifts. Compensation per hour applies to all employees in the nonfarm, business sector and includes private and legally required fringe benefits. Selected nonunion earnings are the weighted average percentage changes in average hourly earnings for the following industries: SIC 533 (variety stores), SIC 56 (apparel stores), SIC 57 (furniture stores), and SIC 60 (banking). Weights used are the levels of production and nonsupervisory employment in 1979.

The three union and two aggregate wage index equations all produce overpredictions, particularly starting in 1982, suggesting that actual wage settlements and decisions have been lower than would have been expected, given economic conditions. This finding applies even when settlements involving wage freezes and cuts are removed from the index of first-year union wage agreements. That is, even those union settlements that did not involve wage freezes and cuts produced surprisingly low wage adjustments.

There is a difference, however, in the performance of the unionoriented indexes and the others with regard to the more recent residuals. 
Table 3. Scheduled Wage Adjustments in First, Second, and Third Years of Union Contracts, 1980-84 Settlements

Percent

\begin{tabular}{ccccccccc}
\hline $\begin{array}{c}\text { Year of } \\
\text { settle- } \\
\text { ment }\end{array}$ & \multicolumn{7}{c}{ Year in which wage adjustment is effective } \\
\cline { 2 - 9 } & 1980 & 1981 & 1982 & 1983 & 1984 & 1985 & 1986 & 1987 \\
\hline 1980 & 9.5 & 8.8 & 6.7 & $\ldots$ & $\ldots$ & $\ldots$ & $\ldots$ & $\ldots$ \\
1981 & $\ldots$ & 9.6 & 8.0 & 7.5 & $\ldots$ & $\ldots$ & $\ldots$ & $\ldots$ \\
1982 & $\ldots$ & $\ldots$ & 7.0 & 7.0 & 6.1 & $\ldots$ & $\ldots$ & $\ldots$ \\
1983 & $\ldots$ & $\ldots$ & $\ldots$ & 4.5 & 4.8 & 4.5 & $\ldots$ & $\ldots$ \\
1984 & $\ldots$ & $\ldots$ & $\ldots$ & $\ldots$ & 4.0 & 4.0 & 4.0 & $\ldots$ \\
$1985^{\mathrm{a}}$ & $\ldots$ & $\ldots$ & $\ldots$ & $\ldots$ & $\ldots$ & 4.0 & 4.0 & 4.0 \\
\hline
\end{tabular}

Source: Bureau of National Affairs, Inc., Daily Labor Report, July 22, 1985, p. B-2; January 22, 1985, p. B-2; January 23, 1984, p. B-5; January 21, 1983, p. B-1; January 22, 1982, p. B-1; January 23, 1981, p. B-2.

a. First six months.

The compensation-per-hour index, which includes many nonunion workers such as managers and supervisors, shows only a small residual by 1984. The hourly-earnings index, which exhibits a larger residual in that year, has a much larger union weight because it excludes supervisory personnel. Thus, there is a strong possibility that the 1984 residuals in the aggregate indexes heavily reflect union sector developments.

Table 2 includes, as a test of this possibility, a nonunion hourlyearnings index for selected industries with low unionization. The low unionization rates ensure not only that there are few union workers covered by the index but also that spillover and "threat" effects from the union sector are minimal. In sharp contrast to the other indexes, this nonunion index is not overpredicted. The suggestion is that the recent slowing of wage growth has been concentrated in the union sector. As will be discussed below, there are good reasons to expect the norm shift phenomenon to be confined to the union sector.

There are also reasons to expect that the current lull in union wage setting will continue in the future. Table 3 shows the first-, second-, and third-year adjustments by year of negotiation as reported from a survey of union settlements by the private Bureau of National Affairs, Inc. (BNA). Settlements involving fifty or more workers are summarized on a biweekly basis in the BNA Daily Labor Report. In the early 1980s, contracts tended to be "front loaded," that is, higher adjustments were scheduled in the earlier years of contracts, probably reflecting declining expectations of inflation and also an expectation of more escalator 
payments, or cost-of-living adjustments, in later years. (Escalator adjustments are excluded from the table.)

During the most recent period shown, contract terms have flattened out to an even 4 percent per year. And, as will be demonstrated below, the flatness is unlikely to reflect expectations of large escalator increases later in the contract since escalator clauses have been limited in union concession agreements. Bargainers appear to expect a continuation of current moderate wage trends.

\section{Concession-Prone Sectors}

U.S. Bureau of Labor Statistics (BLS) data on union wage settlements, such as those used in table 1 , cover only major agreements involving 1,000 or more workers. A more comprehensive survey is undertaken by the BNA, which, as just noted, reports settlements involving fifty or more workers. From that survey, I culled agreements involving firstyear wage freezes or cuts for analysis. Such agreements began to appear in appreciable numbers in late 1981, when they accounted for 3 percent of all settlements reported. The proportion rose to $12,28,27$, and 22 percent in 1982, 1983, 1984, and the first half of 1985, respectively.

Data from the BNA survey reveal that concessions were not evenly spread across industries. In table 4, which shows the industry breakdown of wage freezes and cuts from January 1981 to June 1985, the heavy representation of construction is apparent. Thirty-nine percent of all concessions reported were in construction, many in settlements involving relatively small numbers of workers in particular crafts and cities. A better measure of the concession-proneness of various industries would be the proportion of all settlements in the industry involving concessions. Unfortunately this alternative measure could not be constructed from the data at hand, though some crude calculations suggest that it would yield a picture qualitatively similar to that emerging from table $4 .{ }^{5}$

5. A crude estimate of the proportion of contracts in existence in each sector shown on table 4 can be made from BNA published data by simply summing the number of new settlements reported by sector over the three-year period 1982-84. If all contracts were exactly three years in duration, this technique would be completely accurate. But since the average duration is somewhat less than three years, the technique will give excess 
Table 4. Union Settlements Involving Concessions, January 1981-June 1985 ${ }^{\text {a }}$

Percent

\begin{tabular}{lcc}
\hline \multicolumn{1}{c}{ Industry } & $\begin{array}{c}\text { Industry share } \\
\text { of all wage } \\
\text { freezes and cuts }\end{array}$ & $\begin{array}{c}\text { Wage cuts as } \\
\text { percentage of all } \\
\text { freezes and cuts }\end{array}$ \\
\hline Construction & 39 & 28 \\
Retail food stores & 10 & 34 \\
Metal manufacturing & 9 & 22 \\
Machinery & 6 & 11 \\
Lumber and paper & 4 & 2 \\
Airlines & 4 & 40 \\
Meatpacking & 3 & 60 \\
Printing and publishing & 3 & 6 \\
Motor vehicles & & 9 \\
Aerospace & 3 & 4 \\
All other & 2 & 12 \\
Total & 17 & 23 \\
\hline
\end{tabular}

Source: Biweekly survey by the Bureau of National Affairs, Inc. It covers union settlements involving fifty or more workers.

a. Table is based on 1,185 contracts. Concessions are first-year wage freezes or cuts.

b. Includes related wholesale operations.

c. Includes motor vehicle parts.

A common interpretation of the concession movement is that it reflects deregulation in certain industries and increased foreign competition, associated with the appreciation of the dollar in the early 1980s, in others. Some industries in table 4 easily fit those interpretations. The airline industry, for example, was clearly strongly affected by deregulation that permitted product market competition via price cutting and new entry. And metals, machinery, lumber, and the commercial side of aerospace all suffered from international competition. But not all industries neatly fit the mold.

weight to sectors with a propensity for short contracts. A sector with a higher proportion of concessions than of contracts is concession-prone. Some difficulties arise with this calculation method because the BNA uses more aggregate industry classifications than table 4 for certain sectors. Nevertheless, using approximations where necessary, all sectors listed in table 4 except lumber and paper and printing and publishing appear to be concession-prone. In particular, construction, which had 39 percent of the concessions reported on table 4 is estimated to account for only 18 percent of the contracts. Construction does have a propensity for short contracts so even the 18 percent figure is an overestimate. In the lumber and paper case, most of the major firms have reported concessions in some units, and it is likely that the sector would appear concession-prone if the calculation could be made based on the percentage of workers rather than contracts. 
Construction, the concession leader, was not subject to foreign competition. Nor, it turns out, was deregulation a decisive influence. Certain restrictions on nonunion bidding for federally financed construction projects were weakened through administrative changes in the Davis-Bacon Act in 1982, but because of delays due to litigation, the concession movement in construction was already well established before the most significant Davis-Bacon changes were implemented. ${ }^{6}$

The situation is the same in retail food stores and in printing and publishing. In neither is foreign competition or deregulation an issue. The only product market conditions that could have influenced wage settlements in construction, supermarkets, and printing are the general economic slump of the early 1980s and lower-wage, nonunion competition.

The participation of particular unions in concessions (not reported in the table) is largely a reflection of their representation in concessionprone industries rather than of any inherent propensity to concede. The United Food and Commercial Workers International Union, for example, had the misfortune of representing workers concentrated in retail food stores and meatpacking, both centers of concession bargaining. It accounted for 11 percent of the wage freezes and cuts in the BNA sample, more than any other union. Some unions, such as the Laborers, Plumbers, Operating Engineers, and Plasterers, accounted for significant numbers of concessions solely because of their linkage with the construction industry. Several unions represented workers in construction as well as in other high-concession industries. The Teamsters represent truck drivers in construction and in retail food stores. The Carpenters are in both construction and lumber. The latter two unions each accounted for 7 percent of the freezes and cuts in the BNA sample.

\section{Shifting Wage Norms}

The concept of a shift in wage norms, developed by George L. Perry, suggests that wage-change expectations and targets can be viewed as

6. Proposals for changing Davis-Bacon were originally made by the Reagan administration in 1982, but were not fully in force until early 1985 . Some features were implemented in mid-1983. See "Labor Department Issues Final Rules for Setting Davis-Bacon Wage Rates," Daily Labor Report, February 1, 1985, pp. A3-A4. 
shifting discretely between periods. ${ }^{7}$ For example, Perry argues that wage norms dropped in the early 1960s in response to low price inflation, an extended period of relatively high unemployment, and the federal wage-price guideposts program. They then shifted upward in the 1970s in response to the acceleration of inflation in the 1960s and the price shocks of the mid-1970s.

The importance of the norm shift concept is that it suggests a certain lethargy in the responsiveness of wage expectations and targets. Thus, the period of wage calm that developed in the early 1980s can be expected to herald a period of continued calm, even in the face of moderate real economic expansion. In turn, such a calm would, because of its antiinflationary effects, encourage the continuation of expansionary policies.

Table 5 provides data suggestive of a broad downward shift in wage norms. The table shows that wage freezes and cuts began in a narrow range of industries in 1981 and have been spreading progressively ever since. As the number of industries affected grew, the conventional explanations-deregulation, foreign competition, general economic distress-became harder to credit, and the alternative hypothesis of a demonstration effect became more difficult to reject.

Explanations of the distress in the automobile industry in 1982, for example, do not carry over easily to concessions at Las Vegas hotels and at Disneyland in 1984 . The fact is that management today, in virtually any type of industry, is much more likely to raise product market issues as part of its bargaining tactics than it would have in the 1970s. In a 1985 dispute involving an attempt by San Francisco gravediggers to recoup from a previous one-year wage freeze, management raised the specter of competitive inroads by nonunion cemeteries. ${ }^{8}$ When, as was the case in many of the initial concession settlements, imminent bankruptcy and mass layoffs were threatened, the resulting wage freezes and cuts were easy to rationalize. But the longevity of the concession movement and its spread to less-than-dire situations suggest that the initial concessions have encouraged other employers to try their luck in demanding similar settlements.

Additional evidence of a shift in the wage-setting climate is to be

7. George L. Perry, "Inflation in Theory and Practice," BPEA, 1:1980, pp. 207-41. See also Perry, "What Have We Learned about Disinflation?" pp. 587-602.

8. “Gravediggers Expand Strike,"' Los Angeles Times, March 30, 1985, part 1, p. 31. Ultimately, the strikers did receive a pay increase in this dispute. 
Table 5. The Spread of Concessions, by Industry, January 1981-June $1985^{\mathrm{a}}$

\begin{tabular}{|c|c|c|c|c|}
\hline Industry & 1981 & 1982 & 1983 & $\begin{array}{c}\text { January } \\
\text { 1984- } \\
\text { June } \\
1985\end{array}$ \\
\hline Metals & $\mathrm{X}$ & $\mathrm{X}$ & $\mathrm{X}$ & $X$ \\
\hline Motor vehicles ${ }^{b}$ & $\mathrm{X}$ & $X$ & $\mathrm{X}$ & $\mathrm{X}$ \\
\hline Retail food stores ${ }^{c}$ & $X$ & $\mathrm{X}$ & $\mathrm{X}$ & $\mathrm{X}$ \\
\hline Machinery & $\mathrm{X}$ & $\mathrm{X}$ & $\mathrm{X}$ & $X$ \\
\hline Meatpacking & $\mathrm{X}$ & $\mathrm{X}$ & $\mathrm{X}$ & $\mathrm{X}$ \\
\hline Airlines & $\mathrm{X}$ & $\mathrm{X}$ & $\mathrm{X}$ & $\mathrm{X}$ \\
\hline Printing and publishing & $\mathrm{X}$ & $\mathrm{X}$ & $\mathrm{X}$ & $\mathrm{X}$ \\
\hline Health care & $\mathrm{X}$ & $X$ & $\mathrm{X}$ & $\mathrm{X}$ \\
\hline Lumber and paper & $\mathrm{X}$ & $X$ & $X$ & $\mathrm{X}$ \\
\hline Ordnance & $\mathrm{X}$ & & & $\mathrm{X}$ \\
\hline Construction & & $X$ & $\mathrm{X}$ & $\mathrm{X}$ \\
\hline Transit and bus lines & & $\mathrm{X}$ & $\mathrm{X}$ & $\mathrm{X}$ \\
\hline Rubber & & $X$ & & $\mathrm{X}$ \\
\hline Trucking & & $X$ & $\mathrm{X}$ & $\mathrm{X}$ \\
\hline Aerospace & & $\mathrm{X}$ & $\mathrm{X}$ & $\mathrm{X}$ \\
\hline Textiles & & $\mathrm{X}$ & $\mathrm{X}$ & $\mathrm{X}$ \\
\hline Food manufacturing except meatpacking & & $\mathrm{X}$ & $\mathrm{X}$ & $\mathrm{X}$ \\
\hline Instruments & & $\mathrm{X}$ & $\mathrm{X}$ & $\mathrm{X}$ \\
\hline Chemicals & & $\mathrm{X}$ & $\mathrm{X}$ & $\mathrm{X}$ \\
\hline Furniture & & $\mathrm{X}$ & $\mathrm{X}$ & $\mathrm{X}$ \\
\hline Hotels and restaurants & & $\mathrm{X}$ & $\mathrm{X}$ & $\mathrm{X}$ \\
\hline Shipping & & $\mathrm{X}$ & $\mathrm{X}$ & $\mathrm{X}$ \\
\hline Other transportation equipment ${ }^{\mathrm{d}}$ & & $\mathrm{X}$ & $\mathrm{X}$ & $\mathrm{X}$ \\
\hline Brick, clay, stone & & $\mathrm{X}$ & $\mathrm{X}$ & $\mathrm{X}$ \\
\hline Finance, insurance & & $\mathrm{X}$ & & $\mathrm{X}$ \\
\hline Communications & & $\mathrm{X}$ & & $\mathrm{X}$ \\
\hline Apparel & & $\mathrm{X}$ & & $\mathrm{X}$ \\
\hline Business services & & & $\mathrm{X}$ & $\mathrm{X}$ \\
\hline Railroads & & & $\mathrm{X}$ & \\
\hline Unions $^{e}$ & & & $\mathrm{X}$ & $\mathrm{X}$ \\
\hline Cement & & & $\mathrm{X}$ & $\mathrm{X}$ \\
\hline Entertainment & & & $\mathrm{X}$ & $\mathrm{X}$ \\
\hline Mining & & & $\mathrm{X}$ & $\mathrm{X}$ \\
\hline Warehousing & & & $\mathrm{X}$ & $\mathrm{X}$ \\
\hline Glass & & & $\mathrm{X}$ & \\
\hline Education & & & $\mathrm{X}$ & $\mathrm{X}$ \\
\hline Retail except food stores & & & & $\mathrm{X}$ \\
\hline Leather & & & & $\mathrm{X}$ \\
\hline Petroleum & & & & $\mathrm{X}$ \\
\hline Tobacco & & & & $\mathrm{X}$ \\
\hline Utilities & & & & $\mathrm{X}$ \\
\hline
\end{tabular}

Source: Same as table 4.

a. An " $X$ " indicates the presence of at least one contract involving a concession in the industry and period indicated. Concessions are first-year wage freezes and cuts.

b. Includes motor vehicle parts.

c. Includes related wholesale operations.

d. Transportation equipment excluding motor vehicles and parts and aerospace.

e. Unions in their role as employers of their own staffs. 
found in the union environment itself. Declines in union membership, reduced strike activity, changes in the political and legal balance between unions and management, shifts in management bargaining strategies, and the history of the union-nonunion wage differential all confirm a change.

\section{DECLINING UNION REPRESENTATION IN THE WORK FORCE}

At the same time that wages were behaving in an atypical fashion, union membership began to fall rapidly in the private sector. In May 1980, according to the Current Population Survey, unions represented 15.5 million wage and salary workers in the private sector, a representation rate of 21.7 percent. By 1984, the number represented had declined to some 13 million, and the representation rate, to 17 percent. This national trend was confirmed at the local level by BLS area wage surveys of production worker unionization in medium-to-large establishments. Rates of unionization fell in three-fourths of the metropolitan areas surveyed from 1977-79 to 1980-82.9

The economic slump of the early 1980s particularly affected certain heavily unionized sectors of the work force, such as construction and manufacturing. But industrial composition cannot account for the aggregate representation losses in the union sector. According to data from the BLS on workers covered by major contracts, industrial mix changes can explain only about one-quarter of those losses. ${ }^{10}$

9. See U.S. Bureau of Labor Statistics, Earnings and Other Characteristics of Organized Workers, May 1980, bulletin 2105 (GPO, 1981), table 9; Flaim, "New Data on Union Members." Note that the figures from these sources refer to representation, not membership. Since some nonmembers are represented by unions, representation rates are higher than membership rates. Metropolitan area data are from U.S. Bureau of Labor Statistics, Area Wage Surveys: Selected Metropolitan Areas, 1979 and 1983, bulletins 2050-73 and 3020-73 (GPO, 1981 and 1984).

10. This estimate was made using data on private sector workers covered by major agreements in November 1979 and October 1984 in forty-one industry classifications. The ratio of union workers covered by major agreements in each industry to production and nonsupervisory worker employment was calculated for November 1979. This ratio was then applied to the October 1984 employment figures to estimate a predicted number of union workers. The number of union workers fell from 9.4 million in 1979 to 7.4 million in 1984 , a drop of 2 million, compared with the 500,000 drop predicted by the ratio projections. Thus, only one-fourth of the drop is explained by employment changes. Data on workers under major union agreements appear in Monthly Labor Review, vol. 103 (January 1980), p. 10, and vol. 108 (January 1985), p. 24. 
Unions simply lost more in the 1980s, in terms of both membership and wage settlements, than can be explained by economic circumstances and historical relationships. To the extent that unions lose membership only because of interindustry employment shifts, they need not lose bargaining power, though they might lose some political clout. But losses within industries do suggest weakened bargaining positions due to greater competition with nonunion firms in the product market.

\section{DECREASED STRIKE ACTIVITY}

Strike incidence has always posed an analytical puzzle to economists. In theory, strikes are random "mistakes" made by the parties about each other's true bargaining position. But in fact, strikes seem to reflect shifts in union militancy. Periods of upward adjustment in the wage norm, such as the late 1960s, have been accompanied by heavy strike activity. In contrast, in the early 1960s, when the wage norm was low, strike activity was quiescent.

Table 6 suggests a resemblance between the early 1980s and the early 1960s in this regard. Whether measured by BLS indexes of reported strikes involving 1,000 or more workers or by Current Population Survey reports of individuals with a job but absent from work because of a labor dispute, the level of strike activity accompanying the low wage settlements in the early 1980s fell sharply. Regression analysis also indicates an abnormally low incidence of strikes during the concession period. ${ }^{11}$

There were some bitter disputes in the 1980s. However, in a number of prominent conflicts, such as Continental Airlines Corporation, Phelps Dodge Corporation, and Louisiana-Pacific Corporation, employers succeeded in operating with nonunion personnel, perhaps discouraging other workers from striking in an era of job insecurity. As long as this atmosphere of insecurity persists, as it is likely to do unless unemploy-

11. I ran annual regressions over the period 1959-79 to explain the three strike indexes reported in table 6 . The independent variables were the official unemployment rate and price inflation (CPI-W) lagged one year. Predicted values for 1980-84 exceeded actual values for all years for the number of larger strikes and for all years except 1983 for the indexes of worker involvement. A telephone industry strike in 1983 pushed up worker involvement substantially; had I included a variable for number of workers negotiating, this one deviant result would probably have vanished. Regression results are available from the author. 
Table 6. Work Stoppages, 1960-84

\begin{tabular}{|c|c|c|c|}
\hline Period & $\begin{array}{c}\text { Average annual } \\
\text { number of stoppages } \\
\text { beginning in period } \\
\text { indicated }^{\mathrm{a}}\end{array}$ & $\begin{array}{c}\text { Average annual } \\
\text { number of workers } \\
\text { involved in } \\
\text { stoppages } \\
\text { beginning in } \\
\text { period indicated }\end{array}$ & $\begin{array}{l}\text { Average monthly } \\
\text { number of employees } \\
\text { not at work because } \\
\text { of labor disputes }\end{array}$ \\
\hline $1960-64$ & 211.0 & 883,000 & 44,200 \\
\hline $1965-69$ & 354.8 & $1,584,400$ & 88,200 \\
\hline $1970-74$ & 334.0 & $1,831,000$ & 120,600 \\
\hline $1975-79$ & 243.6 & $1,144,600$ & 110,800 \\
\hline $1980-84$ & 114.2 & 693,000 & 67,200 \\
\hline
\end{tabular}

Sources: U.S. Bureau of Labor Statistics, "Major Work Stoppages: 1984," News, press release USDL: 85-85, February 27, 1985; U.S. Bureau of Labor Statistics, Handbook of Labor Statistics, bulletin 2175 (GPO, 1983), p. 61; Employment and Earnings, various issues.

a. Situations involving 1,000 or more workers.

b. Figures in this column are simple means of the annual averages.

ment rates fall markedly in the union sector, lower wage-change norms can be expected to continue.

\section{THE POLITICAL-LEGAL SETTING}

Since the advent of the Reagan administration, unions have not found encouragement in the processes of labor market regulation. While there have been no changes in basic labor legislation, administrative appointments and changes at agencies such as the National Labor Relations Board (NLRB) are perceived by unions as hostile to their interests. Although legal scholars can debate the wisdom of this or that NLRB or court decision, there is little doubt that the changes in the regulatory climate have complicated union efforts to win substantial pay advances, preserve jobs, and engage in new organizing. ${ }^{12}$ Regulatory changes that hamper job preservation and organizing, in particular, open the door to more nonunion competition and resultant management resistance to union wage demands.

Even before the concession era, attitudes toward collective bargaining were changing. Industrial relations researchers are now finding evidence that in the late $1960 \mathrm{~s}$, a heightened determination to resist new union-

12. This is certainly perceived to be the case by leaders of organized labor. See “" 'Drastic Change' in Legal Climate Drives Unions Away from NLRB Protection," Daily Labor Report, February 13, 1985, pp. C1-C7. 
ization developed in the management community. ${ }^{13}$ This change in management attitudes may well have been linked to the upward shift in wage-change norms, with its accompanying strikes, militancy, and rankand-file rejections of tentative settlements reached by union leaders. In any case, experimentation by employers revealed that the legal system could accommodate increased management resistance to new unionization without substantial penalties.

The 1984 presidential campaign was seen by organized labor as crucial to its future. While the AFL-CIO attempted to put a bright face on the Mondale electoral debacle by noting that a majority of their members supported the Democratic ticket, the large membership losses noted above raise important questions about the future political clout of unions. In the aftermath of Mondale's defeat, the AFL-CIO even began to reconsider whether collective bargaining should remain the centerpiece of its activities. ${ }^{14}$ There is no way of quantifying the impact of these developments on collective bargaining outcomes, but the overall effect will be to prolong the period of lowered wage expectations.

\section{MANAGEMENT BARGAINING STRATEGIES}

Management, cheered by what is perceived as a shift in the balance of power, has changed its bargaining goals. Managers in the 1980s are more concerned with the economic fortunes of their enterprises and less concerned with industry wage patterns than they were in the 1970s. They are also more willing to demand givebacks from unions and less willing to make accommodating trade-offs. ${ }^{15}$

13. For example, an (upward) inflection point can be observed around 1970 in various indexes related to unfair labor practices of employers handled by the National Labor Relations Board. See Richard B. Freeman and James L. Medoff, What Do Unions Do? (Basic Books, 1984), pp. 230-33. A major study has been under way at the Massachusetts Institute of Technology concerning changes in the industrial relations system. The M.I.T. researchers conclude that large, nonunion firms became the leaders in industrial relations innovations "somewhere in the 1960s" as their motivation to remain nonunion increased. See Thomas A. Kochan, Robert B. McKersie, and Harry C. Katz, "U.S. Industrial Relations in Transition: A Summary Report," in Barbara D. Dennis, ed., Proceedings of the Thirty-seventh Annual Meeting, December 28-30, 1984, Industrial Relations Research Association (Madison: IRRA, 1985), pp. 261-76.

14. "Report of the AFL-CIO Committee on the Evolution of Work on the Changing Situation of Workers and Their Unions," Daily Labor Report, February 25, 1985, pp. D1D22.

15. Audrey Freedman, The New Look in Wage Policy and Employee Relations, Report 
The political and legal climate change has been reflected in a greater willingness by management to take actions in labor disputes that might not have been publicly or politically acceptable in the past. Operating with nonunion labor-or threatening to do so-seems more common than was once the case. Even firms with a long history of unionization are using nonunion labor. ${ }^{16}$ During the early 1960 s, there was discussion of a management "hardening" that coincided with a downward wage norm shift; the same symptoms are evident today.

\section{THE UNION-NONUNION WAGE DIFFERENTIAL}

The widening of the union-nonunion wage differential in the 1970s is by now a familiar story. Unfortunately, the BLS did not start explicitly measuring union and nonunion wage trends until the mid-1970s. Thus, estimates of the level of the differential, or the degree to which it widened, will vary depending on data sources.

From 1975, when data for the index began to be collected, to 1982, the BLS Employment Cost Index for wages and salaries indicated a widening of the union-nonunion differential of about 8 percentage points. By early 1985, some 3 points had been subtracted from the 1982 peak. That the differential remains wider today than in the mid-1970s suggests, in concert with other labor market developments noted above, a continued moderate union wage norm.

Apart from its utility as a forecasting device, the union-nonunion wage differential provides insights into the institutional underpinning of the concept of a wage norm shift. For management facing unionized labor, the costs of experimentation in wage settlements are potentially high, because of the strike threat and the bargaining relationship. The union-nonunion wage differential may grow simply because management is reluctant to test its ability to stop it. Labor costs become too high in

865 (New York: Conference Board, 1985), chapters 2 and 3. See also Employer Attitudes toward Compensation Change and Corporate Values (William M. Mercer, Inc., September 1983), p. 13, which reports that two-thirds of the managers surveyed believe that acrossthe-board pay increases will be less important than they have been in the past.

16. For example, Armour Food Co., a well-established firm with a long history of unionization, was recently reported to have closed facilities and replaced 2,000 union workers with nonunion personnel upon reopening. See Henry Weinstein, "Armour Food Draws Fire as NLRB Probes Charges of Hiring Bias," Los Angeles Times, February 19, 1985, part 4, pp. 1,8. 
the long run because short-run calculations of costs and benefits by management suggest the wisdom of a passive response to union demands. Finally, however, a recession pushes managers in certain industries to experiment, and other managers, emboldened, follow the example. In fact, the downward wage norm shift in the 1960s was also preceded by a widening union-nonunion wage differential in the 1950s. History thus has repeated itself in the $1980 \mathrm{~s}$.

\section{Categorizing the Concessions}

Three years ago, I suggested that concessions, and their effects, could be categorized according to the coefficients of a stylized wage-change equation of the form:

$$
w=a+b U^{-1}+c p,
$$

where $U^{-1}$ is the inverse of the unemployment rate (or some other demand-sensitive variable), $p$ is some measure of lagged price inflation, $w$ is the annual rate of wage change, and $a, b$, and $c$ are regression coefficients. ${ }^{17}$ The $a$ coefficient can be viewed as a measure of wage pressure. Given a rate of price inflation and a real measure of labor demand, a large value of $a$ would suggest higher wage increases; a lower value would suggest wage moderation. Similarly, the higher the value of $b$, the greater is wage sensitivity to real demand conditions; and the higher the value of $c$, the greater is wage sensitivity to price inflation. Concessions can be analyzed in terms of their effects on these three coefficients.

\section{CHANGES IN WAGE PRESSURE}

Perry's concept of changing wage "norms" can be discussed in terms of a shift in the $a$ coefficient. In 1983, union wage concessions began to include two features that suggest a drop in wage pressure: first, the substitution of a fixed bonus for a guaranteed wage rate increase and second, pay cuts for entry-level employees. Both changes can be viewed

17. Mitchell, "Recent Union Contract Concessions," pp. 189-92. See also Robert J. Flanagan, "Wage Concessions and Long-Term Union Wage Flexibility," BPEA, 1:1984, pp. 183-216. 
as mechanisms by which a downward shift in wage norms can be accommodated.

Fixed bonuses have been particularly prominent in concessions in three industries. Lumber and paper workers have 28 percent of all fixed bonus plans included in settlements from January 1983 through June 1985; aerospace workers have 16 percent; and retail food store workers, 19 percent. Fixed bonus plans were found in about 30 percent of the wage freeze and cut settlements reported during the first six months of 1985 , up from 8 percent in 1984 , before which they were negligible. The BNA also estimates that such plans were included in some 7 percent of all 1984 agreements, concession and nonconcession; among the latter were the well-publicized General Motors Corporation and Ford Motor Company agreements.

The use of fixed bonus plans has an important wage-change effect, especially in multiyear contracts. A three-year contract containing a 3 percent wage increase each year produces an annual wage 9 percent above the initial base in the third year. In contrast, a bonus plan involving 3 percent lump sum distributions does not raise the basic wage at all and produces a compensation level only 3 percent above the initial base in the third year. Indeed, since such plans often do not pay the bonus to workers employed less than a full year before the payment date, the compensation increase averaged over the entire work force may well be less than 3 percent. ${ }^{18}$

The second contractual feature that reduces labor cost increases is cuts in pay for entry-level employees. These arrangements, commonly called "two-tier wage plans" because of the dual pay or benefit structure created, are more likely than across-the-board pay cuts to win the approval of existing employees in union ratification votes. The plans are of two basic types. Permanent plans create an entirely separate pay structure for new hires, who never catch up with existing workers. Temporary plans provide for a catch-up period, though in some cases the catch-up period is so long-sometimes as much as ten years-that the plan is quasi-permanent. ${ }^{19}$

18. The BLS currently is in a dispute with the aerospace industry over the treatment of bonuses in calculating average hourly earnings. The BLS wishes to exclude the bonuses, while the industry, which has sales contracts indexed to average hourly earnings in SIC 3721 , wants to include them. As a result, earnings data for that industry are currently not being published.

19. For example, the Packard Electric Division of General Motors Corporation 
Just under half of a sample of two-tier contracts collected by the BNA in mid-1984 were of the permanent variety. ${ }^{20}$ A survey of Los Angeles area firms that I conducted with Sanford M. Jacoby found that of those firms reporting two-tier plans, just over half had temporary plans only, almost 30 percent had permanent plans only, and the others had both types. ${ }^{21}$ Although there have been some instances in which unions negotiated the abolition of a two-tier plan, adoption of the plans is still increasing. The BNA reported that 8 percent of all nonconstruction settlements had some type of two-tier system in 1984, up from 5 percent in $1983 .{ }^{22}$

Within the concession sector, the two-tier movement began to appear in 1982; in 1984, 10 percent of concession contracts had provisions reducing entry wage rates; in the first six months of 1985,12 percent of concession contracts had such provisions. Two-tier arrangements were particularly concentrated in the supermarket industry, which had 34 percent of all such plans included in settlements between January 1982 and June 1985. Aerospace and construction each had 11 percent. Twotier plans also figured in several prominent airline settlements that were not concessions as defined here. In construction, where the casual nature of the employer-employee relationship does not lend itself to permanent plans, two-tier plans were mainly cuts in apprentice wages relative to those of journeymen. Those in aerospace may have resulted in part from Defense Department pressure on contractors to hold down labor costs, pressure strongly protested by the unions affected.

Two-tier plans have interesting implications for industrial relations, since, at least under the permanent systems, they involve employees working side by side under separate pay schedules. In cases where skill differentials were narrowed by escalators in the 1970s, two-tier plans

established a ten-year two-tier plan in late 1984. Under the plan, new hires start at 55 percent of the existing worker wage. See "GM Workers at Packard Site Approve New Labor Accord," Wall Street Journal, December 17, 1984, p. 18.

20. The BNA provided the author with a printout of the cases surveyed. The survey was reported in "Two-Tier Wage Contracts Advancing in Popularity," Daily Labor Report, July 11, 1984, pp. B4-B6.

21. Note that the BNA survey was based on number of contracts, while the JacobyMitchell survey was based on the firm as a unit of observation. Firms were asked if any of their wage contracts had two-tier arrangements. See Sanford M. Jacoby and Daniel J. B. Mitchell, "Management Attitudes toward Two-Tier Pay Plans: An Analysis," Journal of Labor Research, forthcoming.

22. "Two-Tier Wage Systems Found More Commonly in Nonmanufacturing Sector," Daily Labor Report, February 20, 1985, pp. B1-B4. 
may be a way of restoring a wide wage spread. However, the implication of two-tier plans for future pay adjustments is simple arithmetic. As long as the proportion of employment in the lower tier is expanding, actual pay adjustments will be lower than those reported for the upper tier.

\section{CHANGES IN RESPONSIVENESS TO DEMAND}

While the concession settlements can be viewed as responsive to demand conditions, this does not imply that a greater responsiveness to demand-a larger $b$ coefficient-can be expected in the future. Examining other characteristics of recent bargains sheds some light on this question. One explanation for past insensitivity of union wages to shortrun demand fluctuations has been the multiyear contract. Such contracts normally prevent wages from reacting to changes in demand after negotiations are concluded. They might also give rise to a multiyear wage-setting horizon that encourages bargainers to ignore economic conditions at the time of negotiations as "transitory."

In general, however, the concession contracts have maintained the multiyear framework, as can be seen in table 7. Contract durations for the concession agreements are slightly below the all-settlement average, but tend to be in the two-and-one-half-year range. Contracts with costof-living adjustment (COLA) clauses tend to be three-year agreements. Those with no COLA average a little over two years in length. Much of the shortening that has occurred is concentrated in construction, an industry that has shown a decided propensity to shift to one-year contracts during previous episodes of wage uncertainty. ${ }^{23}$

Profit sharing, which has been part of some concession agreements, adds an element of wage responsiveness to the business cycle, since profits are likely to reflect cyclical conditions. But profit sharing in the union sector does not appear to be spreading rapidly. In 1981, 10 percent of all concession contracts included profit-sharing plans. In 1984, only 3 percent did so; in the first six months of 1985,4 percent. Measured by workers covered, rather than number of contracts, over 80 percent of the union workers covered by concession agreements with new profitsharing plans are at General Motors and Ford; the overall number of workers covered is probably in the 500,000 to 600,000 range.

23. Arnold R. Weber and Daniel J. B. Mitchell, The Pay Board's Progress: Wage Controls in Phase II (Brookings, 1978), pp. 363-67. 
Table 7. Contract Duration in Settlements with Concessions and in All Settlements, January 1981-June 1985

Months

\begin{tabular}{|c|c|c|c|c|}
\hline \multirow[b]{2}{*}{ Period } & \multicolumn{3}{|c|}{ Concession contracts } & \multirow[b]{2}{*}{$\underset{\text { settlements }}{\text { All }}$} \\
\hline & $\begin{array}{c}\text { With } \\
\text { COLA }\end{array}$ & $\begin{array}{c}\text { Without } \\
\text { COLA }\end{array}$ & $\begin{array}{c}\text { All } \\
\text { contracts }\end{array}$ & \\
\hline 1981 & 32 & 18 & 24 & 32 \\
\hline 1982 & 34 & 26 & 30 & 29 \\
\hline 1983 & 35 & 27 & 29 & 32 \\
\hline 1984 & 34 & 27 & 29 & 31 \\
\hline $1985^{b}$ & 34 & 31 & 32 & 32 \\
\hline January 1981-June 1985 & 34 & 28 & 29 & 31 \\
\hline
\end{tabular}

Sources: Same as table 4 and Daily Labor Report, section B, issues of January 22, 1982; January 21, 1983; January 23, 1984; January 22, 1985; July 22, 1985.

a. Calculated from information appearing in Daily Labor Report on one-year, two-year, and three-year contracts. It was assumed that these contracts had durations of 12,24 , and 36 months, respectively, and that other contracts had durations of 48 months. Results for 1981-85 are weighted by number of settlements in each period's survey. Excludes contracts of unknown duration. Concessions are first-year wage freezes and cuts.

b. First six months.

One reason that profit sharing is not more widespread is that concession bargainers often adopt employee stock ownership plans (ESOPs) instead, primarily because ESOPs are the beneficiary of a variety of strong tax incentives. Thus, from 1983 to 1984, the number of workers, both union and nonunion, covered by ESOPs rose by 19 percent, and the number of ESOPs rose by over 6 percent ${ }^{24}$ Except for the very rare case of 100 percent employee ownership, however, ESOPs do not affect labor costs; they simply spread the equity interest in the firm over a wider range of owners, some of whom happen to be employees.

\section{WAGE SENSITIVITY TO PRICE CHANGE}

The best clue concerning wage sensitivity to price inflation is to be found in the treatment of COLA clauses. According to BLS data, COLAs covered about 59 percent of workers under major private contracts in late 1979 and 57 percent in late 1984 . When 1979 is used as a base period, it appears that changes in industry mix account for almost all of the

24. See "Employee Ownership Plans Jumped to 6,800 in 1984," Daily Labor Report, April 3, 1985, p. A5. Although union-nonunion breakdowns of the plans are not available, there is evidence of growing union interest in ESOPs. See "Acceptance of Employee Stock Ownership Plans Growing within Ranks of Organized Labor," Daily Labor Report, August 26, 1985, pp. C1-C4. 
change; the number of workers covered by COLAs in 1984 was over 95 percent of the level that would have been predicted using 1979 industrylevel COLA propensities. On a contract basis, the actual level was about 86 percent of that predicted. ${ }^{25}$

Management felt "burned" by COLAs in the late 1970s, because of unanticipated inflation and certain aberrations in the CPI. However, the standard reaction in the 1980 s was not to abandon the COLA principle, with the notable exception of a recent Teamsters intercity trucking settlement. Indeed, given the reduction in price inflation, which historically has been associated with elimination of COLA clauses, collective bargainers appear to have stuck to their COLAs with surprising tenacity.

Major contract data suggest, however, that the "quality" of COLAs has deteriorated. During 1980-82, COLAs provided 60-70 percent protection against inflation; that is, a 1 percent increase in prices triggered a $0.6-0.7$ percent wage increase. In 1983-84, the ratio was estimated at a little over 50 percent. ${ }^{26}$

The concession contract data support these findings. Table 8 provides a breakdown of "COLA contracts," concession contracts that either preserved or eliminated a COLA. About 28 percent of the contracts fell into this category, despite the large proportion of settlements in construction, where COLAs are rare. Of the COLA contracts, only 7 percent involved a COLA elimination. Eight percent retained reference to the COLA principle but suspended the operation of the COLA clause for the life of the agreement. Fifty-one percent retained an active COLA clause but limited its operation in some way. The remainder provided for open-ended COLA operation with no limitations.

COLAs can be limited in a number of ways: by diverting COLA money to fringe benefits; placing a cap on payouts regardless of the inflation rate; freezing operation of the COLA below a minimum rate of inflation; eliminating certain payments; reducing the frequency of payments, for example, from quarterly to annual; and delaying payments. With the exception of the last two devices, the COLA limitations will

25. Using the same data source on private sector workers under major contracts cited in footnote 10 , I calculated the ratio of workers with COLAs to the total number of workers under major agreements in each industry as of November 1979. Actual and predicted numbers of workers with COLAs were then calculated for October 1984. The same tabulation was made for number of agreements.

26. These estimates were reported in Current Wage Developments, various issues. 
Table 8. Trends in COLA Clauses in Concession Contracts, January 1981-June 1985 ${ }^{\text {a }}$

\begin{tabular}{lcccc}
\hline & $\begin{array}{c}\text { COLA contracts } \\
\text { as percentage of } \\
\text { all concession } \\
\text { contracts }\end{array}$ & $\begin{array}{c}\text { Sulpended } \\
\text { COL contracts } \\
\text { Sector }\end{array}$ & $\begin{array}{c}\text { COLA contage of } \\
\text { COLAmination } \\
\text { contracts as } \\
\text { percentage of } \\
\text { COLA contracts }\end{array}$ & $\begin{array}{c}\text { Limited COLA } \\
\text { contracts as } \\
\text { percentage of } \\
\text { COLA contracts }\end{array}$ \\
\hline Construction & 7 & 0 & 0 & 45 \\
Other & 42 & 9 & 8 & 51 \\
Total & 28 & 8 & 7 & 51 \\
\hline
\end{tabular}

Source: Same as table 4.

a. COLA contracts are contracts with active or suspended COLA clauses plus contracts eliminating COLA clauses. Concessions are first-year wage freezes and cuts.

produce lower wage costs over the course of a contract. In fact, most of the COLA limitations imposed do reduce the wage adjustment over the life of the contract. ${ }^{27}$

Both the heavy use of COLA limitations in the concession agreements and the BLS data on the lessened degree of real wage protection provided by recent COLA clauses suggest a reduction in the $c$ coefficient in the wage-change equation. As with the other concession features, there is no sure way of predicting the staying power of the innovations. However, the fact that the COLA principle was retained is significant. It is one thing to realign the real or relative wage level through COLA manipulations, another to pretend indefinitely that price inflation does not erode purchasing power. COLA clauses in themselves have typically provided less than 100 percent protection against inflation; yet contracts containing COLAs, including their guaranteed wage increases, have historically provided roughly full protection. ${ }^{28}$ Still, in the near term, COLA restrictions will mean that union wages will be less sensitive to price inflation than they were in the 1970 s.

\section{Implications for Aggregate Wage Change}

Despite its notable shrinkage, the union sector still has a disproportionate weight in aggregate wage indexes, especially average hourly earnings. Union workers earn significant premiums compared with

27. I went back to the original contract listings for the COLA settlements and examined their reported details. The statement in the text is based on this examination.

28. See Mitchell, Unions, Wages, and Inflation, pp. 137-49. 
nonunion workers and also work longer hours per week. Thus, their weight in total payrolls exceeds their weight in total employment. Union wages have a weight of roughly one-third, for example, in the Employment Cost Index. Wayne Vroman estimates that union wages accounted for 48 percent of production worker pay as of 1980, thus giving them substantial weight in the average hourly earnings series. Their weight in average hourly earnings in manufacturing may be on the order of threefourths..$^{29}$ As a result, union-sector wage developments remain important to aggregate wage changes.

Nonunion wages do not mechanically follow union wages; if they did, the union-nonunion wage differential could not have widened as it did in the 1970s. The reversal of the widening trend after 1982 also suggests that the slowing of union wage growth is not being fully reflected in wages of nonunion employees. Of course, many nonunion employees do not work in close proximity to union workers and so might be relatively insulated from wage spillover effects. As a partial test of direct union-to-nonunion spillover in the early 1980s, I used BLS area wage surveys to select metropolitan areas where unionization of production workers was at least 70 percent in manufacturing, but where unionization of clerical workers in the same establishments was below 10 percent. Ten areas met these criteria. Table 9 compares the wage movements of heavily unionized production workers with those of the lightly unionized clerical workers. As can be seen, wages of clerical workers in the selected areas rose more slowly than those of blue-collar workers in the late 1970s, then more quickly from 1982 to 1984 . Thus, the data for nonunion clerical workers in close proximity to unionized production workers exhibit the same tendencies found in general comparisons of nonunion and union wages. Nonunion workers were less affected by the downward norm shift of the 1980s than were union workers.

Of course, some spillovers to the nonunion sector did occur; it is easy to cite particular cases in which executive and nonunion white-collar pay was limited as a quid pro quo or as an inducement for union wage

29. Estimates for the employment cost index were provided to the author by the BLS. On production worker wages, see Wayne Vroman, "Cost-of-Living Escalators and PriceWage Linkages in the U.S. Economy, 1968-1980,' Industrial and Labor Relations Review, vol. 38 (January 1985), p. 227. The estimate for hourly earnings in manufacturing is based on the blue-collar component of the employment cost index, since union weights are not calculated for hourly earnings. 
Table 9. Wage Trends in Selected Metropolitan Areas, 1975-84a

Percent change per year

\begin{tabular}{lccc}
\hline Category of employee & $1975-79$ & $1979-82$ & $1982-84$ \\
\hline Unskilled plant worker & 8.6 & 10.2 & 5.4 \\
Skilled plant worker & 8.6 & 9.4 & 5.3 \\
Office clerical worker & 7.7 & 9.9 & 5.9 \\
\hline
\end{tabular}

Source: U.S. Bureau of Labor Statistics, Area Wage Surveys for selected areas.

a. See text for selection criteria for areas. Figures are simple averages of annualized wage rate changes for ten areas.

concessions. ${ }^{30}$ However, even if such union-to-nonunion spillovers are limited in importance, the union sector is still large enough for a downward shift in its wage norms to affect aggregate wage indexes. If the peak of concessionary settlements has now passed, there could be some "firming" of reported pay adjustments as the proportion of freezes and cuts diminishes. But even those settlements containing positive wage adjustments have been notably moderate in recent years. There is nothing in the labor market that would suggest a reversal of this moderation.

30. For example, International Harvester announced management pay cuts just before requesting union wage concessions in early 1982. See William C. Rempel, "Harvester Asks UAW for Relief," Los Angeles Times, February 19, 1982, part IV, p. 2. 


\section{Comments and Discussion}

Katharine G. Abraham: Daniel Mitchell's paper contains a great deal of interesting material on recent developments in collective bargaining. Rather than walk through all of the useful detailed evidence Mitchell has amassed, I have organized my remarks around the two issues that appear to be central to the paper. The first is how best to interpret the recent slowdown in the growth of union wages. Mitchell estimates a relatively sparse model that overpredicts union wage growth over the past few years, then discusses economic and noneconomic factors that could have contributed to this shortfall of actual union wage growth. An alternative, and in my view preferable, approach would have been to estimate a richer wage growth model that explicitly incorporates the noncyclical economic factors Mitchell believes have affected the growth of union wages. I suspect that such a model would not leave a negative union wage growth residual to be explained in noneconomic terms. The second issue is the path we should expect union wages to follow in the near future. I am less convinced than Mitchell that the mechanisms imbedded in current union contracts will work to moderate wage growth significantly, though my reading of the underlying pressures on union wages leads me to concur that we can expect union wages to grow slowly for at least the next few years.

The main evidence for the argument that the union wage determination process has changed appears in table 2 of the paper. Median first-year union wage adjustments and median effective union wage adjustments were lower in 1983 and 1984 than predicted on the basis of their past relationships with a union-oriented unemployment rate and inflation. In contrast, hourly earnings adjustments in a selected subset of nonunion 
industries recovered to the level predicted on the basis of their past relationship with the overall unemployment rate and inflation.

Whether the below-predicted rate of growth in union wages has what I would consider structural significance depends upon whether the union wage growth prediction equation adequately captures the economic forces that drive wages. I am particularly concerned that the unionoriented unemployment rate, an appealing cyclical variable, may not be a good indicator of longer term influences on the strength of demand for union labor.

It is well known that many of the heavily unionized industries suffered dramatic declines in employment during the early 1980s. My own table 1 reports, for thirteen broad industry aggregates, the share of workers unionized in 1979 and the employment growth rate from 1979 to 1983 and from 1979 to 1984 . Across these broad industry groups, the correlation between the share unionized and the net employment growth rate is -.597 . Many of the heavily unionized industries suffered large net employment losses from 1979 to 1983, while all of the industries with unionization rates below 25 percent experienced net employment growth. This difference in the experience of unionized and nonunionized industries does not appear to reflect only differences in their cyclical sensitivities. The recovery was well established by 1984; nonetheless, the correlation between the share unionized and the net employment growth rate from 1979 to 1984 is - .669, and many of the heavily unionized industries had not regained their 1979 employment levels by 1984 . While it would be difficult to completely disentangle the longer term employment effects of deregulation, foreign competition, technological change, and other factors from the shorter term employment effects of the prolonged cyclical downturn of the early 1980 s, it seems clear that the recession does not fully account for the weak employment performance of the heavily unionized industries in recent years. The union-oriented unemployment rate that underlies the wage predictions in Mitchell's table 2 captures cyclical changes in labor market conditions in unionized industries, but not the continuing problems suggested by the employment statistics. The union-oriented unemployment rate is roughly equal to the overall unemployment rate in 1979; rises above it during the 1980 to 1983 period, reflecting the greater cyclical sensitivity of the heavily unionized industries; and then falls back to rough equality with the 
Table 1. Unionization and Employment Growth Rates across Industries Percent

\begin{tabular}{lccc}
\hline \multicolumn{1}{c}{ Industry } & $\begin{array}{c}\text { Unionization } \\
\text { rate, 1979 }\end{array}$ & $\begin{array}{c}\text { Employment } \\
\text { growth rate } \\
1979-83\end{array}$ & $\begin{array}{c}\text { Employment } \\
\text { growth rate, } \\
1979-84\end{array}$ \\
\hline Mining & 34.9 & 6.7 & 4.3 \\
Construction & 34.0 & -15.0 & -7.1 \\
Durable manufacturing & 38.6 & -13.9 & -8.3 \\
Nondurable manufacturing & 32.0 & -6.5 & -4.0 \\
Transportation & 52.2 & -10.0 & -4.7 \\
Communication and utilities & 50.4 & 4.3 & 7.5 \\
Wholesale trade & 13.4 & 1.2 & 6.9 \\
Retail trade & 10.3 & 2.1 & 8.7 \\
Finance, insurance, and real & & & 14.1 \\
$\quad$ estate & 5.7 & 9.9 & 35.4 \\
Business and repair services & 9.5 & 21.1 & 16.4 \\
Personal services & 7.1 & 6.5 & 12.7 \\
Entertainment and & & & 17.8 \\
$\quad$ recreation services & 15.8 & 11.8 & \\
$\quad$ Professional and related & & 14.6 & \\
$\quad$ services & 22.4 & &
\end{tabular}

Sources: Unionization figures are three-year moving average union membership estimates based on the May Current Population Survey, as reported in Edward C. Kokkelenberg and Donna R. Sockell, "Union Membership in the United States, 1973-1981," Industrial and Labor Relations Review, vol. 38 (July 1985), p. 533. Employment growth rate figures are based on nonagricultural payroll employment data from various issues of Employment and Earnings.

overall rate by $1984 .{ }^{1} \mathrm{I}$ thus do not find it surprising that post-1983 union wage adjustments are lower than predicted on the basis of their past association with the union-oriented unemployment rate.

In addition to not fully capturing the significant differences in the labor demand conditions in more and less heavily unionized industries, the union wage growth predictions in table 2 ignore the fact that domestic nonunion competition, both realized and potential, has become a salient consideration for many unionized enterprises. Mitchell is obviously cognizant of the importance of nonunion competition. Later in the paper, he presents evidence both that the union-nonunion wage differential grew substantially during the 1970 s and that union representation declined more between 1979 and 1984 than could be accounted for by shifts in industry composition. A plausible interpretation of this pattern of

1. The union-oriented (official) unemployment rate was 5.7 (5.8) percent in 1979, 7.8 (7.1) percent in $1980,8.0(7.6)$ percent in $1981,11.0(9.7)$ percent in $1982,10.6(9.6)$ percent in 1983, and 7.6 (7.5) percent in 1984. 
facts is that the growth in the potential cost advantage of operating without a union during the 1970s and the apparent persistence of that advantage encouraged the development of viable nonunion enterprises, which now pose a serious threat to the union sector. Insofar as nonunion substitutes for union goods and services have become more readily available, this growth in nonunion competition seems likely to have increased the elasticity of demand for union labor, a change, standard models suggest, that should lead a union that values both wages and employment to reduce its wage demands. Richard Freeman and James Medoff have provided some cross-sectional evidence that union wage premiums are larger in heavily organized industries. ${ }^{2}$ While it goes beyond their findings to say that an increase in nonunion competition should lead to a relative slowing in the rate of growth in union wages, that proposition is consistent with their results. Moreover, insofar as unions now face greater obstacles to organizing new units than they did in the past, one would expect the threat of nonunion competition to have increased even in cases where the nonunion share of employment has not risen much, particularly in industries with low barriers to entry. Had the intensity of nonunion competition been taken into account in the wage growth equations that underlie table 2 , something that it would admittedly not have been trivial to do, predicted union wage growth would surely have been closer to actual union wage growth.

Mitchell also regards the spread of wage concessions to an increasing number of industries as evidence of a shift in union wage-setting behavior. This spread, however, is less dramatic than table 5 might suggest; fewer than 5 percent of all concession settlements made during 1983, and a similar percentage of all concession settlements made during 1984 or the first half of 1985 , actually represented a "spread." The rest occurred in industries that had already experienced some concession activity during 1981 or $1982 .^{3}$ The factors that explain early concession activity would appear to explain most subsequent concession activity as well.

Whether present union wage moderation is attributable to a shift in the union wage determination process or to economic developments, union wage increases have indeed been quite moderate over the past

2. See Richard B. Freeman and James L. Medoff, "The Impact of the Percentage Organized on Union and Nonunion Wages," Review of Economics and Statistics, vol. 63 (November 1981), pp. 561-72.

3. Mitchell kindly supplied me with these numbers. 
few years; what can we expect over the next few years? The answer to this question will depend both on the features of existing multiyear contracts and on the pattern of new settlements. As an aside, I was rather surprised by Mitchell's evidence that concession agreements had not abandoned the multiyear framework and in fact were almost as long on average as nonconcession agreements. This suggests that the unions signing these agreements generally saw themselves to be accommodating lasting shifts in the economic environment, rather than purely shortterm difficulties.

Mitchell's examination of the features of recently negotiated collective bargaining agreements focuses on the emergence of fixed bonus plans and two-tier wage structures. It should perhaps be emphasized that fewer than 15 percent of collective bargaining agreements currently contain either a fixed bonus plan or a two-tier wage scheme. Moreover, it remains to be seen whether these features are retained in subsequent bargaining rounds. Given the internal political problems that a two-tier wage system seems sure to cause for any union, I would expect these schemes to be short-lived.

Certain features built into current contracts will work to raise future wage increases relative to current wage increases. As Mitchell notes, the ratio of average annual life-of-contract wage increases to first-year increases in major collective bargaining agreements has risen markedly in the past few years. Contracts used to be decidedly front-loaded; BLS data in various issues of Current Wage Developments show that the ratio of annual average life-of-contract to first-year wage increases averaged 0.79 between 1970 and 1979 . That ratio rose from more or less normal levels of 0.75 in 1980 and 0.81 in 1981 to 0.95 in 1982, 1.08 in 1983 , and 1.00 in 1984. These figures could be misleading insofar as increases under COLA clauses are not included; however, BLS data for non-COLA contracts exhibit a similar pattern. The ratio of first-year to average annual life-of-contract wage increases for non-COLA contracts rose from a roughly normal level of 0.88 in 1982 to 1.13 in 1983 and 1.30 in 1984. The findings in table 2 that actual 1984 median first-year union wage adjustments fell 3.2 percentage points short of the predicted adjustment, while actual 1984 median effective union wage adjustments fell only 1.5 percentage points short, are consistent with the shift away from front-loaded contracts. The evidence suggests that deferred wage increases taking effect in 1985 and 1986 will be relatively larger compared 
to first-year wage increases under the same contracts than in the past, thus contributing relatively more to effective union wage growth.

My agreement with Mitchell's conclusion that we can expect moderate union wage increases over the next few years rests more on an assessment of the underlying economic factors than on an analysis of specific contract provisions. The heavily unionized industries appear to be plagued by a variety of problems, and unionized enterprises generally are increasingly threatened by nonunion competition. All this suggests that union wage settlements will remain moderate for the foreseeable future.

\section{General Discussion}

Both Robert Gordon and Charles Schultze expressed concern about a possible problem in the wage growth equations underlying the predicted wage changes in table 2 of Daniel Mitchell's paper. Actual first-year union wage adjustments are below predicted adjustments in every year since 1980, and actual overall union wage adjustments are below predicted adjustments in every year since 1981, even though 1980 and 1981 are generally considered to be prior to the concession period.

Martin Baily viewed the spread in concession activity from a few sectors in 1981 to many sectors in 1984-85, documented in table 5, as fairly persuasive evidence that the recent concessions cannot be linked solely to cyclical conditions; if the concessions were simply a cyclical phenomenon, the number of sectors affected would have risen through 1983, then fallen off. John Shoven wondered whether the apparent continuance and spread of concessions is in part a reflection of the staggered timing of contract expiration dates; a one-time shock that affected the terms agreed upon at the next regularly scheduled renegotiation of each contract might produce a pattern similar to that in table 5.

Much of the discussion focused on the relationship between industry conditions and industry wages. Baily noted that the observed constancy of wage differentials might be the result of institutional rigidities that prevent wages from adjusting, but alternatively might indicate a labor market where mobility costs were low, so that changes in industry conditions would produce movements of workers rather than adjustments in wages. Robert Hall stated his view that collective bargaining 
agreements contain many provisions designed to accommodate shifts in labor demand, so that only shifts in labor supply require contract renegotiation. The fact that concessions have not been limited to industries affected by deregulation or foreign competition provides evidence that shifts in labor supply conditions rather than shifts in product market conditions motivated the wage freezes and cuts.

William Nordhaus was struck by the fact that the union-nonunion wage differential had declined only about 3 percentage points between 1982 and 1985, in spite of the highly adverse conditions faced by the heavily unionized industries. He reported that his own work on industry wage growth suggested that industries subject to deregulation or foreign competition had not experienced slower wage growth than industries sheltered from those pressures, at least through 1984. In Nordhaus's view, these results provide evidence of the surprising stubbornness of wage differentials. Baily noted that determining whether or not a particular industry had been affected by foreign competition could be quite a subtle matter. As an example, he mentioned the chemical industry, which has been significantly affected by foreign competition even though import penetration in the industry itself is low. What has happened is that foreign competition in apparel manufacturing has reduced the domestic demand for synthetic fibers produced by the chemical industry. Lawrence Summers echoed Nordhaus's view that wage structures are surprisingly stubborn; in his own work on nonunion wage differentials, he has found that the cross-industry relative wage structure displays remarkable stability over five- to ten-year periods, even in the face of quite different growth rates across industries.

Mitchell noted that the employment figures cited by Katharine Abraham in her formal comments, showing that employment in unionized industries was lower in both 1983 and 1984 than it had been in 1979, obscured the fact that most of the employment declines in the unionized industries had already occurred by the fourth quarter of 1982, the trough of the recession; after 1982, things generally began to improve. He questioned whether union workers who had lost their jobs in 1982 would exert much influence on union wage settlements reached a year or two years later. Mitchell also pointed to table 9 of the paper, which reports estimated wage growth rates for largely unionized production workers and largely nonunionized clerical workers working for manufacturing employers in ten metropolitan areas. Between 1975 and 1979, the growth rate of the unionized production workers' wages exceeded that of the 
nonunionized clerical workers' wages; between 1982 and 1984, the pattern was reversed. Mitchell noted that product market conditions cannot explain this relative slowing in the rate of union wage growth, since the two groups whose wages enter this comparison work in the same establishments, and he argued that this was additional evidence for his view that something beyond industry conditions had affected recent union wage settlements.

Several participants commented on the growth of the union-nonunion wage differential during the 1970s. Gordon noted that the growth in wages in the heavily unionized U.S. manufacturing sector exceeded the trend rate of growth in productivity from the 1960s onward; indeed, the excess of wage growth over productivity growth was larger in U.S. manufacturing than in that of any of the European countries. Michael Wachter reported that work he has done with Peter Linneman based on Current Population Survey data from 1973 through 1984 shows a systematic negative relationship between the union wage premium within an industry and employment growth in the same industry. Thus Wachter finds it puzzling that union wage premiums have not shrunk more than they have; even many of the recent concession settlements, he observed, have involved temporary wage postponements rather than permanent wage reductions. Stanley Fischer urged that the recent slowing in the rate of union wage growth not be viewed as a lowering of "wage norms," thought of in terms of rates of increase; a more economic approach would be to model recent developments as an overshooting of union wage levels in the 1970s that has to be worked off now.

James Duesenberry took the position that factors such as deregulation, foreign competition, and nonunion competition are likely to have an important effect on union wage growth, but he went on to note the existence of case-by-case evidence of a major shift in the political environment of the collective bargaining process. Employers now demand and receive wage concessions they would never have expected ten years earlier. For example, employers today are quite likely to receive public support for replacing strikers with other workers; ten years ago, strikebreakers would have been termed scabs and their use widely disapproved. However, rather than characterizing the effect of these exogenous shifts in the collective bargaining environment as a shift in the wage norm, Duesenberry argued for the incorporation of political factors in economic models of wage-setting behavior.

Baily took the fact that wage concessions were occurring in conjunc- 
tion with a reduced level of strike activity as evidence that there has been a retreat on the workers' side of the collective bargaining table. He argued that if the recent wage concessions were attributable to a management hardening, as some popular discussion has suggested, one would have expected concessions to be won only with an increase in the number of strikes.

Shoven noted that two-tier wage schemes offer only a temporary slowing in the rate of wage growth. Under a temporary two-tier scheme, an initial slowing in the rate of wage growth will be followed by more rapid wage growth as workers on the bottom tier catch up with those on the top tier; even under a permanent two-tier system, wage growth will be slowed only during the period when new workers are entering the second tier, though that period might last for some time. 